\title{
The differentiation of the immune system towards anti-islet autoimmunity. Clinical prospects*
}

\author{
C.Boitard \\ Service d'Immunologie Clinique, INSERM 25, Hôpital Necker, Paris, France
}

More than one hundred years have elapsed since Oscar Minkowski and Joseph von Mehring first showed that total pancreatectomy induced diabetes mellitus in the dog [1]. Although Minkowski was actually studying the role of non-esterified fatty acids in fat absorption, he was performing the right experiment to establish the first link between the pancreas and Type 1 (insulin-dependent) diabetes mellitus. The link between the pancreas and insulin was established when Banting and Best characterized pancreatic extracts. We now have a good understanding of the mechanisms involved in the selective destruction of islet Beta cells in Type 1 diabetes, the most common form of insulin-dependent diabetes in Europe. Insulitis was first discovered in 1965, when the analysis of pancreata from recent-onset Type 1 diabetic patients revealed an infiltration of the islets of Langerhans by mononuclear cells [2-4], most of which were found to be T lymphocytes expressing activation markers such as class II major histocompatibility complex (MHC) antigens or high-affinity interleukin- 2 receptors [5]. CD8 + T cells are predominant in man, although they may reflect a late phase of the disease process $[5,6]$. In the non-obese diabetic (NOD) mouse, which can be used for sequential analysis of insulitis prior to the development of hyperglycaemia, an initial predominance of CD4 $+T$ cells has now been reported $[7,8]$. The next step was the discovery of islet cell antibodies in $1974[9,10]$; whatever their pathophysiological relevance [11], autoantibodies provide the most reliable diagnostic marker for ongoing anti-islet autoimmunity in normoglycaemic subjects, with a predictive value which reaches $100 \%$ in first-degree relatives of Type 1 diabetic patients with high autoantibody titres [1214]. Other autoantibodies have since been identified [1517] which also have predictive value [18-20].

The third step was the identification of genetic markers for Type 1 diabetes. A genetic background to Type 1 diabetes was strongly suggested by the existence of clinical clusters within families and in twins, while an auto-

\footnotetext{
* This review was first presented as the 26th Minkowski Lecture at the EASD Annual Meeting, Dublin, Ireland, 1991
}

immune mechanism was indicated by the frequent association of Type 1 diabetes with known autoimmune diseases. The conjunction of underlying immune phenomena and the availability of markers for polymorphic structures essential for the cellular interactions involved in immune responses [21], led to the discovery of an association and linkage between insulin-dependent diabetes and defined MHC alleles [22,23]. The association which was first noted with class I MHC alleles (B8, B18, B15) was later shown to be stronger with serological markers for DR-encoded (DR3, DR4) class II MHC alleles $[24,25]$. Class II genes were characterized in the early 1970s as "immune-response genes" controlling reactions to synthetic antigens in the mouse [26] and were thus candidates for the control of autoimmune responses to organspecific autoantigens $[27,28]$.

The fourth, logical step involved an immunological approach to the treatment of Type 1 diabetes [29]. Randomized trials were conducted using cyclosporin A $[30,31]$, azathioprine or steroids or both $[32,33]$. Immunosuppression-induced remissions of insulin-dependence in terms of insulin requirement or C-peptide secretion, thus provided the best evidence so far for the role of autoimmunity in human Type 1 diabetes. But the efficacy of immunosuppression was transient, with relapses occurring within $6-40$ months, thus precluding the use of conventional immunosuppression except in controlled trials. Both the efficacy and secondary failure of this approach probably result from an oversimplified view of the nature of the immunosuppression and the immune reaction to Beta cells, however, new directions for immunointervention derive from this work.

\section{Anti-Beta cell immunity}

The role of $\mathrm{T}$ lymphocytes in the development of antiBeta cell autoimmunity is supported by the predominance of $T$ cells within insulitis, the association of diabetes with defined HLA antigens and the efficacy of T-cell-directed immunosuppression. Studies of human Type 1 diabetes 
come up against the absence of a known autoantigen on Beta cells and the lack of straightforward assays for selfreactive $T$ cells in vitro. As a result, $T$ cells have mostly been studied by enumerating total T-cell subsets or evaluating non-specific $\mathrm{T}$-cell functions. The reported decrease in the CD4 + /CD $8+$ T-cell ratio, the increase in circulating $\mathrm{T}$ cells expressing activation markers $[34,35]$ and the increase in CD4 + T cells expressing the CD45 R marker $[36,37]$ (which presumably mediates delayed-type hypersensitivity and suppressor/inducer functions), all show largely overlapping values with those found in healthy control subjects. This is also the case for normoglycaemic subjects at risk for Type 1 diabetes, precluding the use of these characteristics as diagnostic markers. The study of antigen-specific $T$ cells by means of rosette formation with insulinoma cells $[38,39]$, cells blocking Beta-cell function in vitro [40,41], cytotoxic cells and cells proliferating in the presence of human or xenogeneic islet cells or cell extracts [42] has not been conclusive, given the absence of defined MHC restriction of Beta-cell antigen presentation. The possible role of antigen-presenting cells present in the human cell preparations used, or lymphokines secreted in vitro, has not been thoroughly investigated. The recent demonstration that MHC-restricted autoreactive $\mathrm{T}$ cells specific for a $38-\mathrm{kDa}$ granule protein or glutamate decarboxylase can be detected in Type 1 diabetic patients $[43,44]$ and cloned $[45,46]$ is fundamental. It will nevertheless be difficult to determine whether such clones play a primary role or are rather simply a secondary activation event in human diabetes. Most of what has been learnt about T-cell regulation of anti-islet immunity has come from animal models. Although a fine Tcell regulatory balance controlling $\mathrm{BB}$ rat disease has been described $[47,48]$, this review will refer mostly to the NOD mouse model.

\section{The NOD mouse}

The NOD mouse was first developed in Japan from a cross of JCR $\times \mathrm{JCL}$ mice and brother-sister intercrosses. Most colonies show a female predominance of clinical diabetes. The pancreas remains free of islet infiltration up to 34 weeks of age, but an infiltrate mainly composed of CD4 + T cells then gradually develops. Macrophages are seen at an early stage of the insulitis. Clinical diabetes develops after 10 weeks of age when lymphocytes penetrate the islets and CD8 $+\mathbf{T}$ cells are recruited. Controversial observations of early B-lymphocyte infiltration have been reported. The NOD mouse shows no significant changes in the CD4/CD8 T-cell ratio $[49,50]$. Decreased natural killer cell activity, resistance to herpes virus, increased antibody production to thymo-dependent antigens, deficient activation of suppressor $\mathrm{T}$ cells in syngeneic mixed lymphocyte reactions (MLR) or of cytotoxic T cells in allogeneic or syngeneic MLR, and deficits in cytokine production have all been reported [51-54] but have made no clear contribution to our understanding of the disease process. Salivary and lacrymal gland infiltration, as well as thyroiditis, have been reported in the NOD mouse [55-
57], and autoantibodies have been detected against insulin and islet cell antigens [52, 58-62].

The NOD mouse MHC encodes a unique $A \alpha^{d} / A \beta^{\text {nod }}$ class II antigen which differs from I- $\mathrm{A}^{\mathrm{d}}$ by five amino acid substitutions in the first external domain of the $\beta$ chain, including a serine in position 57 instead of the aspartic acid in conventional mouse strains [63-66]. Crosses between NOD and C57BL/10 mice, which do not express I-E molecules, identified a resistance MHC gene which is not related to I-E [67-69]. The role of I-E antigens in resistance to diabetes is supported by NOC crosses with transgenic $\mathrm{E} \alpha \mathrm{C} 57 \mathrm{BL} / 6$ mice and $\mathrm{E} \alpha^{\mathrm{d}}$ transgenic NOD mice [70,71]. However, following crosses of NON/Lt with the NOD strain, insulitis (although not clinical diabetes) was seen in first-backcross animals expressing I-E antigens [63]. The transfer of $A \beta$ transgenes carrying an aspartic acid at position 57 or a proline at position 56 (instead of histidine) into the NOD genetic background prevents both diabetes and insulitis $[72,73]$. The resistance conferred by I-A antigens carrying aspartic acid at position 57 is, however, questionable since $(\mathrm{NOD} \times \mathrm{C} 57 \quad \mathrm{BL} / 10) \mathrm{F} 1$ chimeras grafted with NOD T-cell-depleted bone marrow show a high incidence of diabetes despite the expression of the I$A \beta^{b}$ chain within the recipient thymus [68]. The role of the MHC background in providing recessive or dominant genes with low penetrance is also controversial. Occasional heterozygotes for the $\mathrm{MHC}$ region develop clinical diabetes. Determining whether diabetes-related genes are susceptibility or resistance genes is likely to require the full characterization of non-MHC genes and their relationship with immune or islet functions. Genetic susceptibility regions have been defined outside the $\mathrm{MHC}$, on chromosomes 1,3 and 10 , by studying crosses/backcrosses of NOD with NON/Lt C57BL/6J, or C57BL/10 mice [74$76]$ and further genes have been identified in NOD $\times$ spretus crosses [77]. This shows the existence of polygenic susceptibility which will have to be taken into account in predictive human genetic tests.

The effect of the NOD phenotype on bone marrow cells has been shown by the transfer of diabetes by NOD marrow stem cells into resistant $(\mathrm{NOD} \times \mathrm{NON}) \mathrm{F} 1$ [78] or $\mathrm{C} 3 \mathrm{H} / \mathrm{HeN}[79]$ chimeras. Similarly, no diabetes or insulitis was observed in Balb/c nu/nu bone marrow-reconstituted NOD $[80,81]$, or $\mathrm{CBA} / \mathrm{J}$ bone marrow-reconstitued $(\mathrm{NOD} \times \mathrm{CBA} / \mathrm{J}) \mathrm{F} 1$ chimeras grafted with NOD islets [82]. In allophenic NOD-C57BL/6 chimeras, the development of insulitis correlates with the NOD phenotype on lymphoid cells and the thymic cortex [83]. The protective role of allogeneic bone marrow antigen-presenting cells was finally evidenced in (NOD $\times$ NOD.H-2 $\left.{ }^{\text {non }}\right) \mathrm{F} 1$ animals reconstituted with a mixture of NOD and NOD.H$2^{\text {non }}$ congenic bone marrow [84].

All immune reactions go through successive steps. The first is antigen presentation, involving both direct interactions between antigen-presenting cells and specific T-cell clones, and indirect interactions mediated by cytokines. Class II MHC antigens are the key structures involved in antigen presentation. The final stage involves effector $T$ cells which directly interact with target cells, and B lymphocytes which produce antibodies. Successive regulatory steps take place between these initial and final phases. 


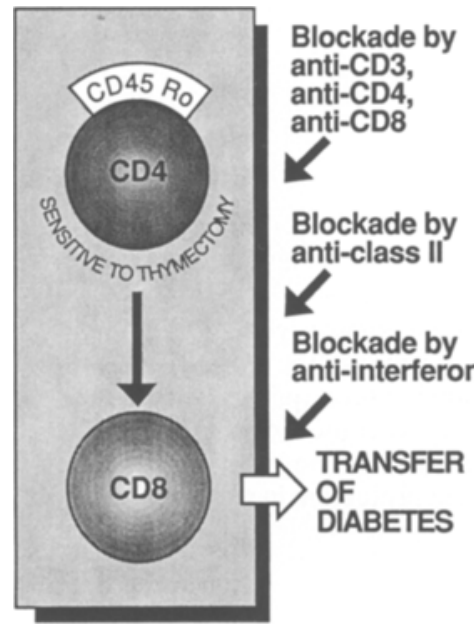

Fig. 1. Characteristic features of diabetes transfer in the NOD mouse
Evidence from cloning experiments that autoreactive $\mathrm{T}$ cells are present in autoimmune conditions is fundamental to this scheme. The successive regulatory steps which take place in the development of diabetes in the NOD mouse need to be addressed both in the diabetic and non-diabetic states to understand why self-tolerance breaks down and to design strategies to restore tolerance.

\section{The direct mechanism of Beta-cell destruction}

Transfer models have been developed with which to study effector mechanisms of Beta-cell destruction. Efficient transfer of diabetes has been obtained following the injection of spleen cells from diabetic NOD donors into both 8 -week-old male NOD recipients (which have a low incidence of diabetes [85]), and naive neonates (as spontaneous diabetes only develops after 10-12 weeks of age [86]). In adult recipients, pre-irradiation was required to achieve efficient transfer; spontaneous insulitis due to recruitment of radioresistant host lymphoid cells may have interferred with transfer. In recipient neonates, the first event was the expression of class II MHC antigens on endothelial cells. Insulitis was characterized by CD4 + T-cell infiltration followed by recruitment of $\mathrm{CD} 8+\mathrm{T}$ cells $[87,88]$. In both recipients, purified $T$ cells from diabetic NOD mice provided efficient transfer. The recruitment of autoreactive B lymphocytes and autoantibody production was not required, since the treatment of recipients with a monoclonal antibody directed against the $\mu$ chain of IgM prior to and after birth did not reduce transfer efficiency despite Beta-cell depletion [89].

In human Type 1 diabetes the role of blocking or cytotoxic autoantibodies remains elusive, as they are not detected in all patients. The lack of strict Beta-cell specificity of islet cell antibodies rules out their participation in Betacell damage. No correlation has been found between the induction of remission upon treatment with cyclosporin A and the presence or pattern of islet cell antibodies $[90,91]$. In the NOD mouse, islets exhibit an impaired glucose metabolism and insulin secretion which are reversed in vitro as islets become depleted of infiltrating cells [92].
Both $\mathrm{CD} 4$ and $\mathrm{CD} 8+$ T-cell subsets are required to transfer diabetes to neonate and adult NOD recipients $[86,93]$, as confirmed by the prevention of transfer by treatment of pre-irradiated adult recipients with antiCD4, anti-CD8 [93-95] or anti-CD3 monoclonal antibodies. We used CD4- or CD8-deprived recipients (thymectomy at 3 weeks) treated with depleting anti-CD4 or anti-CD8 monoclonal antibody to determine the nature of the effector cells. No transfer was achieved with purified CD8 + T cells into CD4-deprived recipients, whereas a low efficiency of transfer was obtained by injecting purified CD4 + T cells into CD8-depleted recipients. However, CD8 depletion, although complete in the periphery as assessed by flow cytometry, was ineffective in islets, where $2-10 \%$ of CD $8+\mathrm{T}$ cells were still present in histological sections.

Beyond the involvement of $\mathrm{T}$ cells, other effector mechanisms have been thought to mediate Beta-cell destruction. Allogeneic islet grafts devoid of class II antigenexpressing (passenger) leucocytes are not rejected through an allogeneic immune response, even in diabetic NOD mice which ultimately show recurrent CD 4 + T-cell infiltration and diabetes across an MHC barrier [96, 97]. The role of non-MHC-restricted natural killer cells in the $\mathrm{BB}$ rat has also been suggested [98-100]. In vitro studies have shown that interleukin-1 exerts selective Beta-cell toxicity in vitro and inhibits insulin secretion by the isolated perfused pancreas $[101,102]$. However, exposure to cytokines of syngeneic islets in contact with allogeneic islets grafted under the kidney capsule does not lead to their destruction in vivo [103] and treatment with tumour necrosis factor or interleukin 1 prevents diabetes in NOD mice [104-107]. The demonstration that $\mathrm{K}^{\mathrm{d}}$-restricted CD8 + T cells from diabetic NOD mice stimulated for $24 \mathrm{~h}$ by interleukin 2 in vitro lyse ${ }^{51} \mathrm{Cr}$-labelled islet cells [108] and the expression of perforin by islet-infiltrating CD8 + T cells on tissue sections [109], both suggest that $\mathrm{CD} 8+\mathrm{T}$ cells are the main effector cells in the disease process, but they require activation by helper CD4 + $T$ cells in transfer models $[88,110]$. The need for a final activation step of effector T cells in the NOD mouse has been confirmed by the prevention of transfer by in vivo treatment of recipients with monoclonal antibodies directed against NOD class II MHC (I-A $\left.{ }^{\text {nod }}\right)$ antigens [111], anti-interferon $\gamma[112,113]$ and anti-macrophage monoclonal antibodies [114] (Fig. 1).

\section{The primary activation step in the immunoregulatory cascade}

The second issue we have addressed in diabetic mice is the level at which the primary activation of the anti-Beta cell immune reaction occurs in the T-cell regulatory cascade. We first investigated at which level of the immune cascade we could prevent the development of diabetes by hitting cell-interaction structures with monoclonal antibodies in vivo. The T-cell receptor is composed for two chains: $\alpha$ and $\beta$ or $\gamma$ and $\delta$. Both include a monomorphic domain anchored to the cell membrane and a variable domain, the antigen recognition unit. Class II MHC antigens are also 


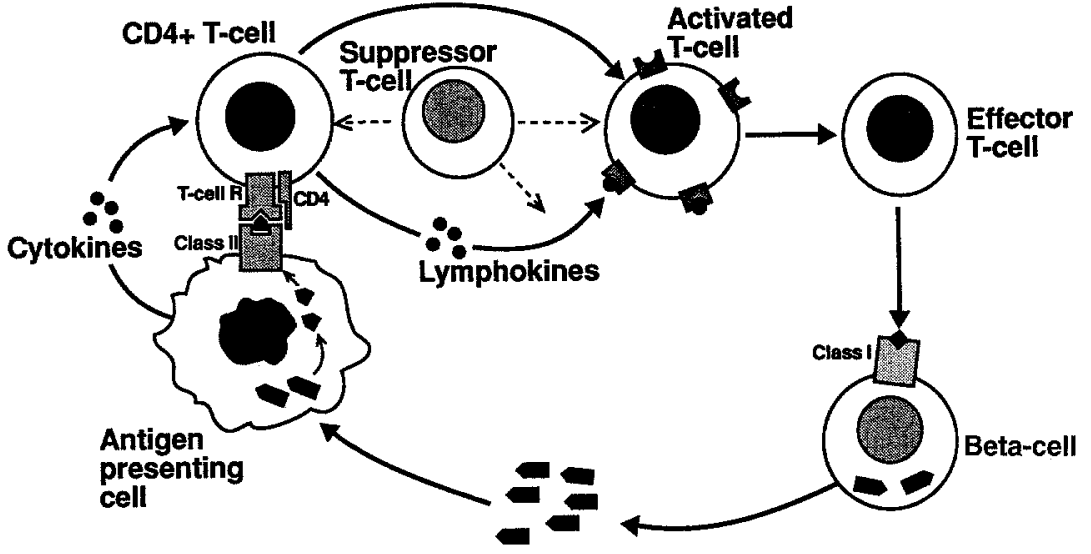

Fig. 2. The $T$ cell regulatory cascade. Defining the primary activation step of the anti-Beta cell autoimmune reaction is a prerequisite of any logical strategy to induce tolerance. Any immune intervention beyond this step may prove useless in inducing long-term protection in susceptible individuals composed of two chains, each with two extracellular domains which carry antigenic peptides on antigen-presenting cells. Anti-CD4 monoclonal antibody treatment prevents diabetes in the NOD mouse $[115,116]$ and other models $[117,118]$. We similarly found that spontaneous Type 1 diabetes is prevented long term by treating female NOD animals with a monoclonal antibody directed against either the monomorphic domain of the T-cell receptor $\beta$ chain [119] or private epitopes on NOD class II MHC antigens [111]. Thus, the interaction between antigen-presenting cells and CD $4+\mathrm{T}$ cells is central to the autoimmune activation process.

The role of antigen expression in the primary activation of the anti-islet immune response was addressed by evaluating autoreactive Tcells in Beta-cell deprived NOD mice in comparison with naive NOD animals. The capacity of T cells from diabetic NOD mice, but also from ageing non-diabetic animals, to transfer diabetes into preirradiated 8-week-old recipients was used as a marker of autoimmune activation. Beta-cell-deprived animals were obtained by a single injection of a toxic dose of alloxan at 3 weeks of age and were maintained on insulin treatment for up to 6 months. The activation of autoreactive $T$ cells, evaluated at 6 months by the capacity of spleen T cells to transfer diabetes, was not seen in alloxan-treated animals. Alloxan or insulin treatment and sustained hyperglycaemia in spontaneously diabetic animals did not alter their capacity to transfer diabetes. Autoreactive T cells are thus not activated in autoantigen-deprived animals. The primary activation step traces back to an antigenpresenting cell-CD4 interaction and Beta-cell antigen expression (Fig. 2).

\section{The role of regulatory $T$ cells in the NOD mouse}

There is indirect evidence that suppressor mechanisms may control the development of diabetes in non-diabetic animals. First, an acute form of diabetes is induced by cyclophosphamide in young NOD mice [120]; second, thymectomy at 3 weeks accelerates the development of diabetes in female animals [121]; finally, irradiation is required to achieve successful transfer of diabetes [85], showing a protection state in adult recipient animals. To evaluate this protection state, we reconstitued irradiated adult recipients with lymphoid cells from non-diabetic animals and evaluated their capacity to protect against the transfer of diabetes. Reconstitution with spleen cells from non-diabetic 8-week-old NOD females was able to protect against the transfer of diabetes by spleen cells from diabetic animals. Protective spleen cells were shown to be $\mathrm{CD} 4+\mathrm{T}$ cells and were not detected in mice thymectomized at 3 weeks, or in NOD neonates, indicating either that the $\mathrm{T}$ cells were short-lived or that they colonized the periphery after 3 weeks of age [122]. In this model CD4mediated suppression was shown to be specific for the islet immune reaction. The role of suppressor CD4 + T cells was also demonstrated by the successful transfer of diabetes in non-irradiated thymectomized 8-week-old NOD recipients, as long as prior depletion had been performed with anti-CD4 monoclonal antibody. The role of the thymus in the NOD model has been strengthened by evidence of a maturation defect of thymic T cells [123] and an intrinsic defect of the T-cell response to concanavalin $\mathrm{A}$ and anti-CD3 antibodies [124]. The significance of these defects with regard to morphological abnormalities of thymic cortex epithelial cell architecture is unknown $[125,126]$ (Fig. 3).

Two functional types of CD $4+\mathrm{T}$ cells have been found in the NOD mouse. One activates the transfer of diabetes, while the second shows suppressor activity. Interestingly, $\mathrm{CD} 4+\mathrm{T}$ cells have been subdivided, on the basis of different lymphokine secretion patterns, into TH1 (interleukin 2 and interferon $\gamma$ ) and $\mathrm{TH} 2$ subsets (interleukin 4 and 6). Data assigning definite functions to cells showing the two patterns of lymphokine secretion remain controversial. Phenotypic markers can also be used to discriminate between CD4 subsets. On the basis of CD45 expression, the expression of low-molecular-weight (CD45 RO) and high-molecular-weight (CD45 RA, B or C) antigens depends on alternative splicing of exons 4,5 and 6 of the CD45 gene. We used monoclonal antibodies which recognize high-molecular-weight isoforms in the mouse to study the distribution of CD45 RA + CD4 + T cells in the NOD model. CD45 RA expression has been associated with the TH1 subset in man, and the distribution of CD45 $\mathrm{RA}+$ cells was modified in mature NOD thymic T-cell populations. A considerable increase in CD45 RA CD4 + T cells was found in NOD lymph nodes between 1 and 3 months of age. Moreover, most infiltrating CD4 + 


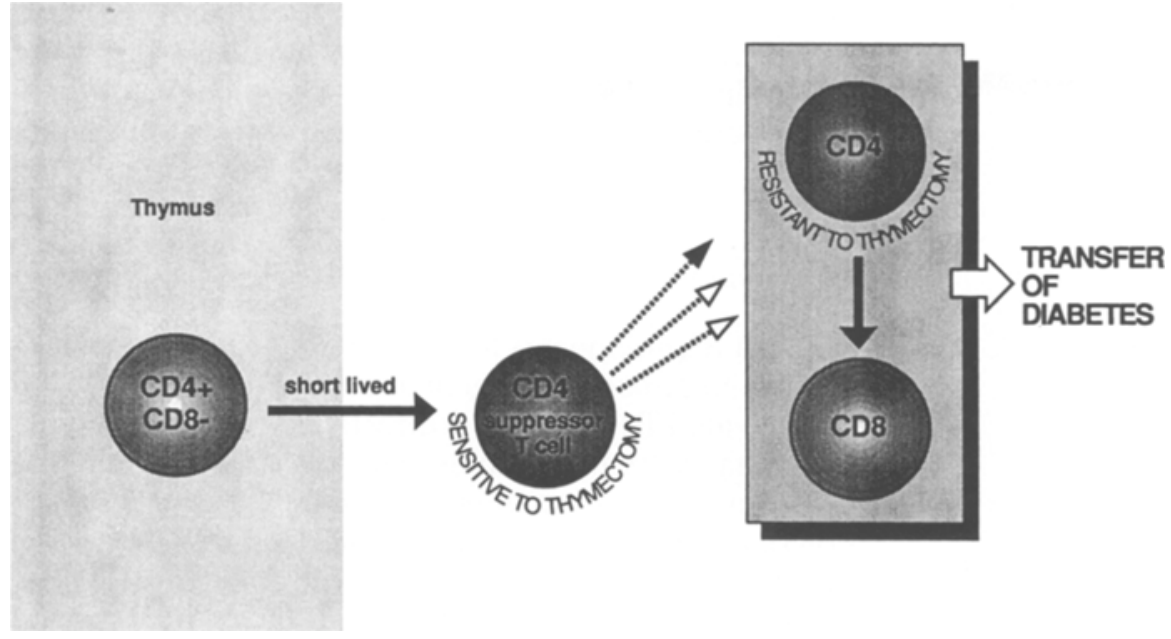

Fig. 3. The role of regulatory $\mathrm{T}$ cells in NOD mouse diabetes. Evidence for suppressor $\mathrm{CD} 4+\mathrm{T}$ cells relies on functional experiments in the NOD mouse. A molecular characterization of these regulatory T cells (i.e. antigen specificity, T-cell receptor) will require the isolation of T-cell clones with suppressor functions
T cells in the pancreas were CD45 RA + . The treatment of NOD mice with an anti-CD45 RA monoclonal antibody from 12 to 32 weeks of age was as efficient as antiCD4 monoclonal antibody treatment in preventing the development of Type 1 diabetes and insulitis. By contrast, the transfer of diabetes was not influenced by CD4-CD 45 depletion of diabetic spleen cells or treatment of recipients with the same anti-CD45 RA monoclonal antibody (P. Sempé, unpublished results). The NOD mouse disease thus involves complex regulatory pathways in which CD4 + CD45RA + T cells may be involved in early immune activation but not in late activation steps involved in disease transfer. Preliminary evidence also suggests that suppressor CD4 + T cells co-express CD45 RA.

\section{Molecular characterization of CD4 $+T$ cell-antigen presenting cell interactions}

Experiments have so far been based on functional parameters. The results indicate key interaction between $\mathrm{CD} 4+\mathrm{T}$ cells and antigen-presenting cells in the NOD model, and the need for the molecular characterization of interaction structures on autoreactive CD4 and antigenpresenting cells. Initial support for this idea has come from the identification of biochemical constraints in the amino acid sequence of the external domain of the $\beta$ chain of the class II antigen-presenting structure [127]. Position 57 (located at the end of the $\alpha$ helix), may affect the insertion of the autoantigenic peptide into the antigenpresenting cleft on the dimeric class II molecule.

Characterization of the T-cell receptor for antigen on autoreactive $T$ cells raises the major issue of restricted variable-region (V) gene usage, with both theoretical and therapeutic implications. Different V $\beta$ gene families have been identified by preventing diabetes with anti-V $\beta$ monoclonal antibodies in vivo and by studying autoreactive T-cell clones, ruling out $V \beta$-specific immunotherapy in this model [128-130]. The study of (NOD $\times$ SWR) intercrossbackcross animals which show a deletion of $V \beta 5,8,9,11-$ 13 genes confirmed that receptors using these genes are not mandatory for the development of diabetes [131, 132].
The third structure to be characterized is the peptide inserted within the class II cleft on antigen-presenting cells. Two approaches have so far been developed to define putative target autoantigens. One is the study of Tcell clones which proliferate specifically in response to islet-cell-derived antigens [133-140]. The second is the study of the antigenic specificity of polyclonal sera with islet cell reactivity. In the NOD mouse, we identified circulating autoantibodies against a $58-\mathrm{kDa}$ antigen by Western blot analysis of Rin5F cell extracts. Autoantibodies were detected in all diabetic NOD mice tested, and in nondiabetic mice from the first weeks of the onset of insulitis. A monoclonal antibody against the $58-\mathrm{kDa}$ antigen was used to test a large panel of non-islet-related cell lines, and revealed the expression of the $58-\mathrm{kDa}$ antigen on a murine neuroblastoma cell line. This allowed us to identify the 58$\mathrm{kDa}$ antigen as peripherin, an intermediate filament protein which is expressed by peripheral neuronal cells. The sequence of the neuronal protein has been determined. None of the other cell lines tested (including thymic, fibroblast, and pituitary cells) express peripherin [62,141-143].

Interestingly, other putative autoantigens have been evidenced in the NOD mouse, including insulin $[59,60]$, heat-shock protein $65[137,138]$ and a $64-\mathrm{kDa}$ antigen [144] probably corresponding to that characterized in human Type 1 diabetes. These are part of an increasing list of autoantigens against which autoantibodies or autoreactive $T$ cells have been identified in man and which may have therapeutic implications in Type 1 diabetes. Extensive characterization of T-cell reactivity to these antigens, including autoreactive epitope mapping, and their role in initiating or relaying the autoimmunization process will be required: this is an easier task in animal models (in which tolerance induction can be tested as a strategy to prevent the activation of autoreactive $T$ cells) than in human Type 1 diabetes.

\section{Immunotherapy: clinical prospects}

The goal of immunotherapy in Type 1 diabetes is to induce long-term protection following transient therapeutic intervention. Cyclosporin studies indicate that suppres- 
Table 1. Target autoantigens in Type 1 (insulin-dependent) diabetes mellitus

Insulin, proinsulin

Glycolipids, ganglioside GT3

$64 \mathrm{kDa}$ antigen, glutamic acid decarboxylase

Carboxypeptidase H, PM-1, polar antigen

38-kDa secretory granule membrane component

Peripherin

Heat-shock protein 65

Insulin receptor

Endocrine cell antigens

Cytoskeleton proteins (tubulin, actin) Reticulin

Nuclear antigens (ssDNA, ssRNA)

sion of T-cell activation blocks the anti-islet immune reaction in man. However, the transient effect observed is likely to be a major drawback with all conventional immunosuppressive agents. Immunological efficacy is hampered by side-effects due to toxicity to non-lymphoid tissues. The effect on CD $4+\mathrm{T}$ cells, whatever their antigenic specificity, results in broad untargetted immunosuppression. Other limits arise directly from the mechanisms of action of cyclosporin. Cyclosporin binds to a cytosolic receptor with peptidylprolyl isomerase activity, resulting in the blockade of interleukin-2 gene transcription and T-cell proliferation $[145,146]$. The action of cyclosporin is thus restricted to resting $\mathrm{T}$ cells which is a major limitation since most islet infiltrating cells are activated; it is also a likely explanation for the delayed clinical action of cyclosporin in Type 1 diabetes. Finally, the treatment has a very narrow safety margin since at the time of clinical hyperglycaemia a majority of Beta cells have already been destroyed.

Major guidelines should direct future immunointervention strategies. The first involves the step from therapy to prevention, but diagnostic tests for the diabetic susceptibility background will be required. The second involves going from immunosuppression to tolerance induction. Inducing tolerance prior to the first activation of autoreactive T cells, as proposed in the case of insulin [147], will require defining human target autoantigens and the epitopes involved, which may prove tedious. However, intermediate approaches between conventional immunosuppression and antigen-mediated tolerance induction may be feasible (Table 1 ).

Past strategies may have been based on an oversimplified view of both immunosuppression and the diabetes process. The mechanisms of action of immunosuppressive agents can differ greatly. Some kill targetted cells, while others alter cell function, and ultimately opposite effects on immune responses may be seen. The disease process is complex, involving a sequence of activating or regulatory events; these include homing of $\mathrm{T}$ cells to the islets of Langerhans, followed by effector events at the onset of clinical diabetes when the immune system has already differentiated and Beta-cell destruction is occurring. From a therapeutic point of view, modification of regulatory T-cell function and elimination of effector $T$ cells directly involved in Beta-cell destruction are both likely to involve more than one agent. Long-term protection may indeed require a combination of the two approaches. Finally, it is likely that modulating autoreactive T-cell activation will require interference at the very first activation step of the autoimmune regulatory cascade, i.e. the interaction between autoreactive CD $4+T$ cells and antigen-presenting cells.

\section{The requirements of an intermediate strategy}

The first requirement is to dissociate induction and maintenance treatments. The goal of induction treatment is to kill activated $\mathrm{T}$ lymphocytes directly at the islet site, while maintenance treatment aims to restore or induce immune self-tolerance to islet antigens by modulating the activation of autoreactive $T$ cells, thus bypassing the presented autoantigens. The next requirement is to target a restricted T-cell repertoire which includes islet-specific $T$ cells. Finally, it will be necessary to intervene earlier in the natural history of Type 1 diabetes, before the onset of clinical hyperglycaemia, when autoreactive $\mathrm{T}$ cells are being activated against islet cell antigens.

\section{Experimental bases}

First, it is possible to eliminate insulitis rapidly in the NOD mouse by using monoclonal antibodies such as anti-T cell or anti-CD45 RA in association with anti-CD8 monoclonal antibodies. Eight-week-old NOD mice treated with anti-T cell receptor antibody also show almost complete clearance of destructive insulitis within 9 days. The same induction treatment reverses the diabetic state in animals with recent-onset hyperglycaemia [119]. A similar result may be obtained by targetting the T-cell receptor for interleukin $2[148,149]$.

The induction of tolerance by modulating T-cell activation while bypassing the autoantigen, is also possible in the NOD mouse. In the recent years several mechanisms have been proposed to account for tolerance to self antigens. The selection of the T-cell repertoire, including that of autoreactive T cells, is mainly a thymic process involving negative and positive selection of precursor cells. There is evidence for negative selection through the deletion of autoreactive clones as a mechanism of tolerance induction in the case of superantigens and class II MHC antigens expressed on bone-marrow-derived cells. Positive selection of autoreactive clones has been shown to involve class II antigens expressed by thymic cortical epithelial cells $[150,151]$. The maintained tolerance of non-deleted self-reactive clones may involve various mechanisms: clonal anergy is one in which $\mathrm{T}$ cells are present but are incapable of secreting interleukin 2 when activated. Other mechanisms include peripheral T-cell suppression. The site of antigen expression largely influences self-tolerance-induction pathways. Antigens expressed or presented within the thymus may induce deletion, while those only expressed in the periphery are more likely to participate in tolerance through anergy, suppression or defective antigen presentation to specific T cells [152154]. A wide antigen-specificity repertoire, but a small number of cells within each antigenic specificity or clone is an economic necessity of the immune system. The activa- 


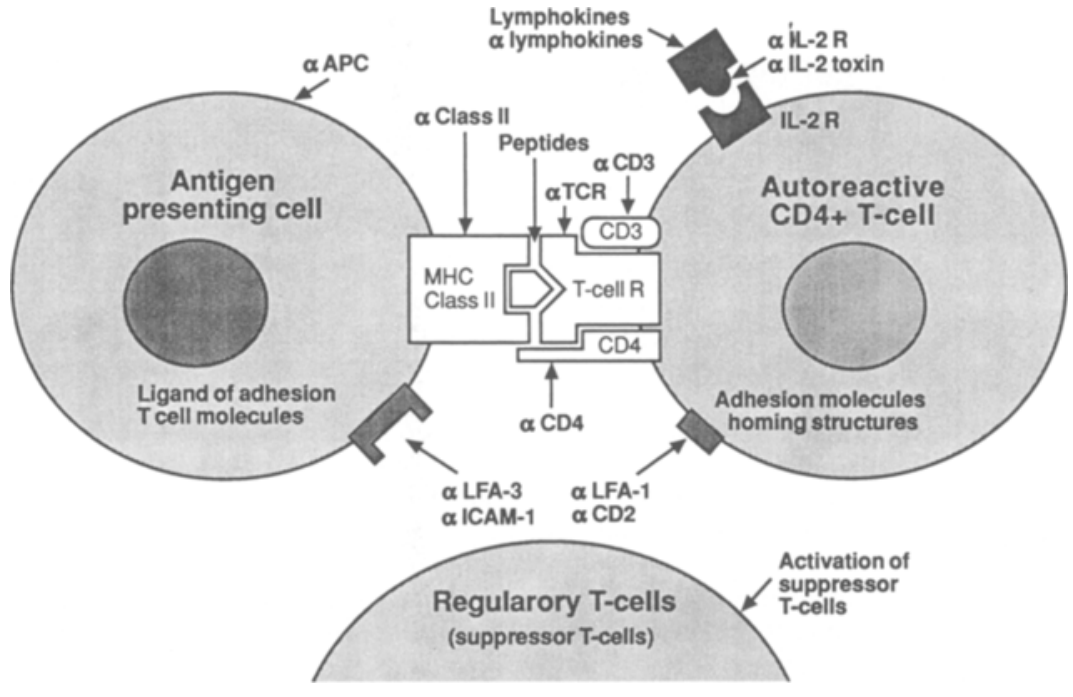

Fig.4. New approaches to immunosuppression. The physiology of T-cell activation follows a two signal model in vitro. The absence of a "co-stimulatory" signal may induce active T-cell unresponsiveness and ultimate tolerance (e.g. anergy). IL, Interleukin; TCR, T-cell receptor tion and proliferation of a specific clone in response to a given antigenic specificity is thus necessary for host defenses. The physiology of T-cell activation is similar to the two-signal model proposed in the early 1970 s by Bretscher and Cohn for B-lymphocyte activation. One signal is mediated by the cognate interaction of T-cell receptor with specific peptides presented on MHC antigens. The occupancy or cross-linking of the T-cell receptor generates the activation of phospholipase $\mathrm{C}$ and tyrosine kinases. These pathways allow the activation of lymphokine genes such as interleukin 4 , while others remain unactivated (e.g. interleukin 2 ). The second signal occurs via different interaction structures on cell membranes, possibly including CD28. Whatever the second co-stimulation signal, occupancy of the T-cell receptor, combined with the delivery of a co-stimulatory signal, leads to T-cell activation. By contrast, occupancy of the T-cell receptor in the absence of a co-stimulatory signal is not a neutral event: this form of signalling induces active $T$ cell unresponsiveness [155].

The NOD mouse also provides clues on tolerance induction. Several approaches referring to tolerance induction at the thymic level using anti-CD3 antibodies $[156,157]$ or by generation of effector cells using streptococcal preparations [158] have been reported. Along the same line reversal of the diabetes process has been observed following adjuvant immunotherapy [159]. Longterm treatment of NOD mice with anti-class II antibodies prevents the development of Type 1 diabetes in female NOD mice. In addition, the same antibodies induce a state of unresponsiveness which is not a simple blockade effect on antigen presentation, but reflects an active induction of suppressor T cells [160]. By blocking antigen presentation and the normal delivery of activating signals by the T-cell receptor, anti-class II treatment may induce a protection state satisfying some of the criteria of tolerance. In protected animals, suppressor $\mathrm{CD} 4+\mathrm{T}$ cells are generated which can transfer protection to untreated recipients. Animals that receive spleen cells from anti-class IItreated donors are protected against diabetes following injection of spleen cells from diabetic animals. Anti- class II is not only effective in preventing diabetes when treatment is maintained up to the end of protection experiments, but also when injected within a very narrow time-frame. Anti-class II treatment was effective longterm when applied from 3 to 7 weeks of age in animals free of insulitis at the start of treatment. By contrast, animals treated later (from 8 to 16 weeks of age) were only transiently protected. Spleen cells collected at 40 weeks from the animals treated at an early stage were unable to transfer diabetes, in contrast to spleen cells from non-diabetic animals treated with a control antibody, which rendered $88 \%$ of the recipients diabetic. The strong protection state induced by anti-class II treatment may be related to tolerance, since evidence has been obtained that protection is islet-specific in anti-class II-treated animals. Moreover, parenteral cyclophosphamide treatment of protected animals at 6 months of age failed to induce acute diabetes, but was successful in control animals. Similar evidence of tolerance induction in the mouse has been obtained in other models with anti-CD4. A major issue is whether the same protection that was induced with anti-class II can be achieved once the autoimmune process has started. Experiments are needed to induce tolerance in animals with an ongoing autoimmune process, but this may only be possible following induction treatment to eliminate insulitis and target lymphocytes that are already committed. This is a prerequisite for new therapeutic strategies in man, and is half-way between conventional immunosuppression and antigen-mediated tolerance induction.

The tools for induction and maintenance treatment (Fig. 4) may already be available for human use (Table 2). Some are even aimed at a narrow T-cell repertoire which includes autoreactive islet-specific T-cell clones. A fusion toxin has recently been obtained as a recombination product associating the interleukin-2 gene and part of the diphtheria toxin gene. Interleukin 2 is the recognition unit and the toxin fragment $\mathrm{A}$, the killing unit. Interleukin 2 delivers the toxin only to cells expressing high-affinity interleukin-2 receptors [148]. Less than $5 \%$ of circulating $\mathrm{T}$ cells usually express such high-affinity receptors, whereas most of those infiltrating islets are activated and 
Table 2. New immunosuppression tools for use in man

\begin{tabular}{ll}
\hline Induction treatment: & Cytotoxic anti-CD4 \\
& Anti-CD3 \\
& Anti-T-cell receptor \\
& Fusion toxins \\
& Low-dose cyclosporin A \\
Maintenance treatment: & Anti-class II \\
& Non cytotoxic anti-CD4 \\
& Cytokines \\
& Anti-cytokine \\
& Tolerance
\end{tabular}

thus express them. This approach exemplifies the strategies which will be developed both to affect a limited spectrum of $T$ cells within the T-cell repertoire and as induction treatment of ongoing autoimmune processes. Maintenance treatments aimed at achieving long-term protection must also be developed. Candidate agents include low-dose cyclosporin and monoclonal antibodies against interaction structures expressed by antigenpresenting cells and CD4 + T cells; human monoclonal antibodies prepared by genetic engineering technology are already available for human therapeutics.

\section{Conclusions}

Defining adapted therapeutic strategies may require further insight into the pathophysiological mechanisms involved in anti-islet autoimmunity. The precise series of events which initiate the anti-islet T-cell autoimmune reaction is still hypothetical. The presence of autoreactive $T$ cells with a genetic background defined by specific $\mathrm{MHC}$ genes and other undefined susceptibility genes is thought to be the prerequisite for the development of autoimmune diabetes. Triggering factors have been postulated which may initiate $[154,161]$ or prevent [162] the activation of autoreactive $\mathrm{T}$-cell clones. The triggering role of environmental factors is supported by experimental evidence that autoimmune islet Beta-cell destruction can be induced by Beta-cell-toxic agents or $\beta$ cytotropic viruses in animals, but proof has not been obtained in human diabetes. Recent studies suggest a role for interferon $\gamma$ both on Beta-cell antigen expression and as inducer of an immune reaction at the islet site [163, 164].

Several non-exclusive hypotheses may explain the development of autoimmunity to Beta cells. The presence of autoreactive $T$ cells may result from defective selection of the T-cell repertoire (e.g. absence of negative selection or abnormal positive selection). The role of T-cell selection in determining the peripheral T-cell repertoire and autoimmune susceptibility has been shown in the collagen arthritis model [165], but remains hypothetical in the case of diabetes. Extensive study of the T-cell repertoire in health and disease will thus be required before firm conclusions can be drawn.

In the presence of specific $T$ cells, tolerance to self antigens has been shown to result from anergy (defined by the presence of autoreactive $T$ cells, along with a T-cell incapacity to produce interleukin 2 in response to specific antigens), T-cell mediated suppression, and unresponsiveness of effector (CD4 and CD8) T cells, each possibly overcome by the autoimmune process.

Our growing knowledge of the mechanisms of peripheral $\mathrm{T}$-cell tolerance allows new immunointervention strategies. These may permit therapies aimed at inducing tolerance independently of defining autoantigens and peptides involved in the primary activation of autoreactive $T$ cells and, possibly, the chain-reaction underlying anti-Beta cell autoimmunity.

Acknowledgements. All concepts presented here follow the lines of thought of four people with whom I successively met and worked. My first debt is to the late Jean Hamburger; for teaching us how to combine biology and medicine. Hugh O. N. McDevitt; his interpretation of functional experiments led to the molecular characterization of a central piece of the immune puzzle, the major histocompatibility complex. Jean François Bach; for bringing clinical immunology to the frontiers of research and medicine. Roger Assan; I was his first resident when he founded his department at the Hôpital Bichat; he established therapy guidelines still followed in Type 1 diabetes. I would like to acknowledge Monique Debray-Sachs, Chantal Becourt, Marie-Françoise Richard, Pascal Sempé, Etienne Larger. Maria Carme Villa and José Timsit with whom I am currently working and all collaborators (past and present) to whom I feel greatly indebted. I thank Martine Netter and Michèle Pitte who prepared this manuscript (as well as previous ones). Finally, I am grateful to my wife Elisabeth. I dedicate this work to her and our three children.

\section{References}

1. Luft R (1989) Oskar Minkowski: discovery of the pancreatic origin of diabetes, 1889. Diabetologia 32: 399-401

2. Gepts W, De Mey J (1965) Pathologic anatomy of the pancreas in juvenile diabetes mellitus. Diabetes 14: 619-633

3. Gepts W, Lecompte PM (1981) The pancreatic islets in diabetes. Am J Med 70: 105-115

4. Foulis AK, Stewart JA (1984) The pancreas in recent-onset type 1 (insulin-dependent) diabetes mellitus: insulin content of islets, insulitis and associated changes in the exocrine acinar tissue. Diabetologia 26: 456-461

5. Bottazzo GF, Dean BM, McNally JM, MacKay EH, Swift PGF, Gamble RD (1985) In situ characterization of autoimmune phenomena and expression of HLA molecules in the pancreas in diabetic insulitis. $\mathrm{N}$ Engl J Med 313:353-360

6. Sibley RK, Sutherland DER, Goetz F, Michael AF (1985) Recurrent diabetes mellitus in the pancreas iso- and allograft. Lab Invest 53: 132-144

7. Miyazaki A, Hanafusa T, Yamada K et al. (1985) Predominance of $\mathrm{T}$ lymphocytes in pancreatic islets and spleen of pre-diabetic non-obese diabetic (NOD) mice: a longitudinal study. Clin Exp Immunol 60: 622-630

8. Signore A, Pozzilli P, Gale EAM, Andreani D, Beverley PCL (1989) The natural history of lymphocyte subsets infiltrating the pancreas of NOD mice. Diabetologia 32: 282-289

9. Bottazzo GF, Florin-Christensen A, Doniach D (1974) Islet-cell antibodies in diabetes mellitus with autoimmune polyendocrine deficiencies. Lancet II: 1279-1282

10. MacCuish AC, Barnes EW, Irvine WJ, Duncan LJP (1974) Antibodies to pancreatic islet cells in insulin-dependent diabetics with coexistent autoimmune disease. Lancet II: 1529-1531

11. Lernmark $\AA$, Baekkeskov S (1981) Islet cell antibodies - theoretical and practical implications. Diabetologia 21: 431-435

12. Tarn AC, Dean BM, Schwarz G et al. (1988) Predicting insulindependent diabetes. Lancet I: $845-850$

13. Bonifacio E, Bingley PJ, Shattock M et al. (1990) Quantification of islet-cell antibodies and prediction of insulin-dependent diabetes. Lancet I: 147-149 
14. Srikanta S, Gando OP, Rabizadeh A, Soeldner JS, Eisenbarth GS (1985) First-degree relatives of patients with type 1 diabetes mellitus. N Engl J Med 313: 461-464

15. Wilkin T, Armitage M, Casey C et al. (1985) Value of insulin autoantibodies as serum markers for insulin-dependent diabetes mellitus. Lancet I: $480-482$

16. Palmer JP, Asplin CM, Clemons P et al. (1983) Insulin antibodies in insulin-dependent diabetics before insulin treatment. Science 222: 1337-1339

17. Baekkeskov S, Aanstoot HJ, Christgau S et al. (1990) Identification of the $64 \mathrm{~K}$ autoantigen in insulin-dependent diabetes as the GABA-synthesizing enzyme glutamic acid decarboxylase. Nature 347: 151-156

18. Atkinson MA, MacLaren NK, Scharp DW, Lacy PE, Riley WJ (1990) $64000 \mathrm{M}_{\mathrm{r}}$ autoantibodies as predictors of insulin-dependent diabetes. Lancet 335: 1357-1360

19. Baekkeskov S, Landin M, Kristensen JKetal. (1987) Antibodies to a $64000 \mathrm{M}_{\mathrm{I}}$ human islet cell antigen precede the clinical onset of insulin-dependent diabetes. J Clin Invest 79:926-934

20. Palmer JP, McCullock DK (1991) Prediction and prevention of IDDM-1991. Diabetes 40: 943-947

21. Cosgrove D, Gray D, Dierich A et al. (1991) Mice lacking MHC class II molecules. Cell 66: 1051-1066

22. Singal DP, Blajchman MA (1973) Histocompatibility (HL-A) antigens, lymphocytoxic antibodies and tissue antibodies in patients with diabetes mellitus. Diabetes 22: 429-432

23. Nerup J, Platz P, Ortved Anderson A et al. (1974) HL-A antigens and diabetes mellitus. Lancet II: 846-866

24. Cudworth AG (1978) Type 1 diabetes mellitus. Diabetologia 14: $281-291$

25. Svejgaard A, Platz P, Ryder LP (1980) Insulin-dependent diabetes mellitus. Histocompatibility testing. In: Taraski PI(ed) Report of the 8th International Histocompatibility Workshop, Los Angeles. Regents of University of California Press, pp 638-656

26. Benacerraf B, McDevitt HO (1972) Histocompatibility-linked immune response genes. Science 175: 273-279

27. Todd JA, Acha-Orbea H, Bell JI et al. (1988) A molecular basis for MHC class II-associated autoimmunity. Science 240: 10031009

28. Nepom GT (1991) MHC class-II molecules and autoimmunity. Ann Rev Immunol 9: 493-525

29. Stiller CR, Dupré J, Gent M et al. (1984) Effect of cyclosporine immunosuppression in insulin-dependent diabetes mellitus of recent onset. Science 223: 1362-1367

30. Feutren G, Assan R, Karsenty G et al. (1986) Cyclosporin increases the rate and length of remission in insulin-dependent diabetes of recent onset. Lancet II: 119-124

31. The Canadian-European Randomized Control Trial Group (1988) Cyclosporin-induced remission of IDDM after early intervention. Diabetes 37: 1574-1582

32. Harrison LC, Colman PG, Dean B, Baxter R, Martin FIR (1985) Increase in remission rate in newly diagnosed type 1 diabetic subjects treated with azathioprine. Diabetes 34: 13061308

33. Silverstein J, MacLaren N, Riley W, Spillar R, Radjenovic D, Johnson S (1988) Immunosuppression with azathioprine and prednisone in recent-onset insulin-dependent diabetes mellitus. N Engl J Med 319: 599-604

34. Boitard C, Bach JF (1986) Cell-mediated versus humoral immunity in autoimmune diseases and their pharmacologic control with particular reference to type 1 diabetes mellitus. Concepts Immunopathol 3: 193-224

35. Prud'homme GJ, Parfrey NA (1988) Biology of disease. Role of T helper lymphocytes in autoimmune diseases. Lab Invest 59: 158-172

36. Faustman D, Eisenbarth G, Daley J, Breitmeyer J (1989) Abnormal T-lymphocyte subsets in type 1 diabetes. Diabetes 38 : 1462-1468

37. Faustman D, Schoenfeld D, Ziegler R (1991) T-lymphocyte changes linked to autoantibodies. Association of insulin auto- antibodies with CD4 + CD45R + lymphocyte subpopulation in prediabetic subjects. Diabetes 40:590-597

38. Huang SW, MacLaren NK (1976) Insulin-dependent diabetes: a disease of autoaggression. Science 192: 64-66

39. Lang F, Maugendre D, Houssaint-Chalmeau E, Charbonnel B, Sai P (1987) Cytoadherence of lymphocytes from type 1 diabetics to insulin-secreting cells: a marker of anti- $\beta$ cell cellular immunity. Diabetes 36: 1356-1364

40. Boitard C, Debray-Sachs M, Pouplard A, Assan R, Hamburger $\mathrm{J}$ (1981) Lymphocytes from diabetics suppress insulin release in vitro. Diabetologia 21:41-46

41. Boitard C, Chatenoud L, Debray-Sachs M (1982) In vitro inhibition of pancreatic B cell function by lymphocytes from diabetics with associated autoimmune diseases: a T cell phenomenon. J Immunol 129: 2529-2535

42. Harrison LC, De Aizurua H, Loudovaris T et al. (1991) Reactivity to human islets and fetal pig proislets by peripheral blood mononuclear cells from subjects with preclinical and clinical insulin-dependent diabetes. Diabetes 40: 1128-1133

43. Roep BO, Kallan AA, Hazenbos WLW et al (1991) A 38 kDa insulin-secretory granule protein is a major antigen for $\mathrm{T}$ cell from recent onset type 1 diabetes patients. Lancet 337: 14391441

44. Atkinson MA, Kaufman DL, Campbell L et al (1992) Response of peripheral-blood mononuclear cells to glutamate decarboxylate in insulin-dependent diabetes. Lancet 339: 458459

45. Roep BO, Arden SD, de Vries RRP, Hutton JC (1989) Human T cell clones with specificity for insulinoma cell antigens. Eur J Immunol 19: 213-216

46. Roep BO, Arden SI, de Vries RRP, Hutton JC (1990) T cell clones from a type 1 diabetes patient respond to insulin secretory granule proteins. Nature 345: 632-634

47. Greiner DL, Handler ES, Nakano K, Mordes JP, Rossini AA (1986) Absence of the RT-6 T cell subset in diabetes-prone BB/W rats. J Immunol 136: 148-151

48. Greiner DL, Mordes JP, Handler ES, Angelillo M, Nakamura N, Rossini AA (1987) Depletion of RT6.1 + T lymphocytes induces diabetes in resistant biobreeding/Worcester $(\mathrm{BB} / \mathrm{W})$ rats. J Exp Med 166: 461-475

49. Lampeter EF, Signore A, Gale EAM, Pozzili P (1989) Lessons from the NOD mouse for the pathogenesis and immunotherapy of human type 1 (insulin-dependent) diabetes mellitus. Diabetologia 32: 703-708

50. Boitard C, Bach JF (1991) Insulin-dependent diabetes mellitus: an autoimmune disease. In: Talal $\mathrm{N}$ (ed) Molecular autoimmunity. Academic Press, San Diego, pp 273-318

51. Kataoka S, Satoh J, Fujiya H et al. (1983) Immunologic aspects of the nonobese diabetic (NOD) mouse. Abnormalities of cellular immunity. Diabetes 32: 247-253

52. Pontesilli O, Carotenuto P, Gazda LS, Pratt PF, Prowe SJ (1987) Circulating lymphocyte populations and autoantibodies in nonobese diabetic (NOD) mice: a longitudinal study. Clin Exp Immunol 70: 84-93

53. Faustman D, Li X, Lin HY (1991) Linkage of faulty major histocompatibility complex class I to autoimmune diabetes. Science 254: 1756-1761

54. Serreze DV, Leiter EH (1988) Defective activation of T suppressor cell function in nonobese diabetic mice. Potential relation to cytokine-deficiencies. J Immunol 140: 3801-3807

55. Bernard NF, Ertug F, Margolese H (1991) High incidence of thyroiditis and anti-thyroid autoantibodies in NOD mice. Diabetes 41: 40-46

56. Leiter EH, Serreze DV (1991) Autoimmune diabetes in the nonobese diabetic mouse: suppression of immune defects by bone marrow transplantation and implications for therapy. Clin Immunol Immunopathol 59: 323-334

57. Goillot E, Mutin M, Touraine JL (1991) Sialadenitis in nonobese diabetic mice: transfer into syngeneic healthy neonates by splenic T lymphocytes. Clin Immunol Immunopathol 59: $462-473$ 
58. Kanazawa Y, Komeda K, Sato S, Mori S, Akanuma K, Takaki F (1984) Non-obese-diabetic mice: immune mechanisms of pancreatic $\beta$-cell destruction. Diabetologia 27: 113-115

59. Reddy S, Bibby NJ, Elliott RB (1988) Ontogeny of islet cell antibodies, insulin autoantibodies and insulitis in the non-obese diabetic mouse. Diabetologia 31:322-328

60. Michel C, Boitard C, Bach JF (1989) Insulin autoantibodies in non-obese diabetic (NOD) mice. Clin Exp Immunol 75: 457460

61. Karounos DG, Thomas JW (1990) Recognition of common islet antigen by autoantibodies from NOD mice and humans with IDDM. Diabetes 39: 1085-1090

62. Villa MC, Bécourt C, Pham Gia H et al. (1992) Autoantibodies against pancreatic $\beta$-cells: characterization by Western blot analysis in the non-obese diabetic (NOD) mouse. J Autoimmunity 5: 47-58

63. Prochazka M, Leiter EH, Serreze DV, Coleman DL (1987) Three recessive loci required for insulin-dependent diabetes in nonobese diabetic mice. Science 237:287-289

64. Acha-Orbea $\mathrm{H}, \mathrm{McD}$ evitt $\mathrm{HO}$ (1987) The first external domain of the nonobese diabetic mouse class II I-A $\beta$ chain is unique. Proc Natl Acad Sci USA 84: 2435-2439

65. Ikegami H, Eisenbarth GS, Hattori M (1990) Major histocompatibility complex-linked diabetogenic gene of the nonobese diabetic mouse. J Clin Invest $85: 18-24$

66. Acha-Orbea H, Scarpellino L (1991) Nonobese diabetic and nonobese nondiabetic mice have unique MHC class II haplotypes. Immunogenetics 34: 57-59

67. Wicker LS, Miller BJ, Coker LZ et al. (1987) Genetic control of diabetes and insulitis in the nonobese diabetic (NOD) mouse. J Exp Med 165: 1639-1654

68. Wicker LS, Miller BJ, Chai A, Terada M, Mullen Y (1988) Expression of genetically determined diabetes and insulitis in the nonobese diabetic (NOD) mouse at the level of bone marrowderived cells. J Exp Med 167: 1801-1810

69. Wicker LS, Miller BJ, Fischer PA, Pressey A, Peterson LB (1989) Genetic control of diabetes and insulitis in the nonobese diabetic mouse. J Immunol 142: 781-784

70. Nishimoto H, Kikutani H, Yamamura KI, Kishimoto T (1987) Prevention of autoimmune insulitis by expression of I-E molecules in NOD mice. Nature 328: 432-434

71. Lund T, O'Reilly L, Hutchings P et al. (1990) Prevention of insulin-dependent diabetes mellitus in non-obese diabetic mice by transgenes encoding modified I-A $\beta$-chain or normal I-E $\alpha$ chain. Nature 345: 727-729

72. Miyazaki T, Uno M, Uehira M et al. (1990) Direct evidence for the contribution of the unique I- $\mathrm{A}^{\mathrm{nod}}$ to the development of insulitis in non-obese diabetic mice. Nature 345: 722-724

73. Slattery RM, Kjer-Nielsen L, Allison J et al. (1990) Prevention of diabetes in non-obese diabetic I-A ${ }^{\mathrm{k}}$ transgenic mice. Nature 345: 724-726

74. Todd JA, Aitman TJ, Cornall RJ et al. (1991) Genetic analysis of autoimmune type 1 diabetes mellitus in mice. Nature 351: $542-547$

75. Comall RJ, Prins JB, Todd JA et al. (1991) Type 1 diabetes in mice is linked to the interleukin-1 receptor and Lsh/Ity/Bcg genes on chromosome 1. Nature 353:262-264

76. Garchon HJ, Bedossa P, Eloy L, Bach JF (1991) Identification and mapping to chromosome 1 of a susceptibility locus for periinsulitis in non-obese diabetic mice. Nature 353:260-261

77. de Gouyon B, Melanitou E, Richard MF, Requarth M, Hahn IH, Guenet JL, Demenais G, Julier C, Lathrop GM, Boitard C, Avner $\mathbf{P}$ (in press) Genetic analysis of diabetes in insulitis in an inter-specific cross of the NOD (non-obese-diabetic-mouse) with Mus spretus. Proc Natl Acad Sci USA

78. Serreze DV, Leiter EH, Worthen SM, Shultz LD (1988) NOD marrow stem cells adoptively transfer diabetes to resistant $($ NOD $\times$ NON) F1 mice. Diabetes 37: 252-255

79. Ikehara S, Kawamura M, Takao F et al. (1990) Organ-specific and systemic autoimmune diseases originate from defects in hematopoietic stem cells. Proc Natl Acad Sci USA 87: 8341-8344
80. Ikehara S, Ohtsuki H, Good RA et al. (1985) Prevention of type 1 diabetes in nonobese diabetic mice by allogeneic bone marrow transplantation. Proc Natl Acad Sci USA 82: 77437747

81. Yasumizu R, Sugiura K, Iwai H et al. (1987) Treatment of type 1 diabetes mellitus in non-diabetic mice by transplantation of allogeneic bone marrow and pancreatic tissue. Proc Natl Acad Sci USA 84: 6555-6557

82. Serreze DV, Leiter EH, Shultz LD (1990) Transplantation analysis of $B$ cell destruction in (NOD $\times \mathrm{CBA}$ ) $\mathrm{F} 1$ mouse bone marrow chimeras. Diabetologia 33: 8492

83. Forsgren S, Dahl U, Söderström A, Holmberg D, Matsunaga T (1991) The phenotype of lymphoid cells and thymic epithelium correlates with development of autoimmune insulitis in NOD C57BL/6 allophenic chimeras. Proc Natl Acad Sci USA 88: 9335-9339

84. Serreze DV, Leiter EH (1991) Development of diabetogenic $\mathrm{T}$ cells from NOD/Lt marrow is blocked when an allo- $\mathrm{H}-2$ haplotype is expressed on cells of hemopoietic origin, but not on thymic epithelium. J Immunol 147: 1222-1229

85. Wicker LS, Miller BJ, Mullen Y (1986) Transfer of autoimmune diabetes mellitus with splenocytes from nonobese diabetic (NOD) mice. Diabetes 35: 855-860

86. Bendelac A, Carnaud C, Boitard C, Bach JF (1987) Syngeneic transfer of autoimmune diabetes from diabetic NOD mice to healthy neonates. Requirement for both L3T4 + and Lyt-2+ T cells. J Exp Med 166: 823-832

87. Bedossa P, Bendelac A, Bach JF, Carnaud C (1989) Syngeneic $T$ cell transfer of diabetes into NOD newborn mice: in situ studies of the autoimmune steps leading to insulin-producing cell destruction: Eur J Immunol 19: 1947-1951

88. Thivolet C, Bendelac A, Bedossa A, Bach JF, Carnaud C (1991) $\mathrm{CD} 8+\mathrm{T}$ cell homing to the pancreas in the nonobese diabetic mouse is CD4 + T cell-dependent. J Immunol 46: 85-88

89. Bendelac A, Boitard C, Bedossa P, Bazin H, Bach JF, Carnaud C (1988) Adoptive T cell transfer of autoimmune nonobese diabetic mouse diabetes does not require recruitment of host B lymphocytes. J Immunol 141:2625-2628

90. Mandrup-Poulsen T, Nerup J, Stiller CR et al. (1985) Disappearance and reappearance of islet cell cytoplasmic antibodies in cyclosporin-treated insulin-dependent diabetics. Lancet I: 599-602

91. Boitard C, Feutren G, Castano L et al. (1987) The effect of cyclosporin A treatment on the production of antibody in insulin-dependent (type 1) diabetic patients. J Clin Invest 80: $1607-1612$

92. Strandell E, Eizirik DL, Sandler S (1990) Reversal of $\beta$-cell sup pression in vitro in pancreatic islets isolated from nonobese diabetic mice during the phase preceding insulin-dependent diabetes mellitus. J Clin Invest 85: $1944-1950$

93. Miller BJ, Appel MC, O'Neil J, Wicker LS (1988) Both the Lyt-2 + and L3T4 + T cell subsets are required for the transfer of diabetes in nonobese diabetic mice. J Immunol 140:5258

94. O'Reilly LA, Hutchings PR, Crocker PR et al. (1991) Characterization of pancreatic islet cell infiltrates in NOD mice: effect of cell transfer and transgene expression. Eur J Immunol 21: $1171-1180$

95. Hutchings P, Simpson E, O'Reilly LA, Lund T, Waldmann H, Cooke A (1990) The involvement of Lyt $2+T$ cells in beta cell destruction. J Autoimmunity 3: 101-109

96. Wang Y, Hao L, Gill RG, Lafferty KJ (1987) Autoimmune diabetes in NOD mouse is L3T4 T-lymphocyte dependent. Diabetes 36: 535-538

97. Wang Y, Pontesilli O, Gill RG, La Rosa F, Lafferty KJ (1991) The role of CD $4+$ and CD $8+$ T cells in the destruction of islet grafts by spontaneously diabetic mice. Proc Natl Acad Sci USA 88: $527-531$

98. MacKay P, Jacobson J, Rabinovitch A (1986) Spontaneous diabetes mellitus in the $\mathrm{BB} / \mathrm{W}$ rat: evidence in vitro for natural killer cell lysis of islet cells. J Clin Invest 77: 916-924 
99. Woda BA, Padden C (1987) Biobreeding/Worcester (BB/Wor) rats are deficient in the generation of functional cytotoxic T cells. J Immunol 139: 1514-1517

100. Bellgrau D, Lagarde AC (1990) Cytotoxic T-cell precursors with low-level CD8 in the diabetes-prone biobreeding rat: implications for generation of an autoimmune T-cell repertoire. Proc Natl Acad Sci USA 87: 313-317

101. Bendtzen K, Mandrup-Poulsen T,Nerup J, Nielsen JH, Dinarello CA, Svenson M(1986) Cytotoxicity of human pl 7interleukin1 for pancreaticislets of Langerhans. Science 232:1545-1547

102. Mandrup-Poulsen T, Bendtzen K, Dinarello CA, Nerup J (1987) Human tumor necrosis factor potentiates human interleukin 1-mediated rat pancreatic beta cell cytotoxicity. J Immunol 139: 4077-4082

103. Sutton R, Gray DWR, McShane P, Dallman MJ, Morris PJ (1989) The specificity of rejection and the absence of susceptibility of pancreatic islet $\beta$ cells to nonspecific immune destruction in mixed strain islets grafted beneath the renal capsule in the rat. J Exp Med 170: 751-762

104. Satoh J, Seino H, Abo T et al. (1989) Recombinant human tumor necrosis factor $\alpha$ suppresses autoimmune diabetes in nonobese diabetic mice. J Clin Invest 84: 1345-1348

105. Jacob CO, Also S, Michie S, McDevitt HO, Acha-Orbea H (1990) Prevention of diabetes in nonobese diabetic mice by tumor necrosis factor (TNF): similarities between TNF- $\alpha$ interleukin 1. Proc Natl Acad Sci USA 87:968-972

106. Satoh J, Seino H, Shintani S et al. (1990) Inhibition of type 1 diabetes in BB rats with recombinant human tumor necrosis factor $\alpha$. J Immunol 145: 1395-1399

107. Campbell IL, Oxbrow L, Harrison LC (1991) Reduction in insulitis following administration of IFN- $\gamma$ and TNF- $\alpha$ in the NOD mouse. J Autoimmunity 4:249-262

108. Nagata M, Yokono K, Hayakawa M et al. (1989) Destruction of pancreatic islet cells by cytotoxic $\mathrm{T}$ lymphocytes in nonobese diabetic mice. J Immunol 143: 1155-1162

109. Young LHY, Peterson LB, Wicker LS, Persechini PM, Ding E, Young J (1989) In vivo expression of perforin by CD8 + lymphocytes in autoimmune diseases. J Immunol 143: 3994-3999

110. Hanafusa T, Sugihara S, Fujino-Kurihara H et al. (1988) Induction of insulitis by adoptive transfer with L3T4 + Lyt2- T-lymphocytes in T-lymphocyte-depleted NOD mice. Diabetes 37: 204-208

111. Boitard C, Bendelac A, Richard MF, Carnaud C, Bach JF (1988) Prevention of diabetes in nonobese diabetic mice by anti-I-A monoclonal antibodies. Transfer of protection by splenic T cells. Proc Natl Acad Sci USA 85: 9719-9723

112. Campbell IL, Kay TWH, Oxbrow L, Harrison LC (1991) Essential role for interferon- $\gamma$ and interleukin- 6 in autoimmune insulin-dependent diabetes in NOD/Wehi mice. J Clin Invest 87 : 739-742

113. Debray-Sachs M, Carnaud C, Boitard Cetal. (1991) Prevention of diabetes in NOD mice treated with antibody to murine IFN $\gamma$. J Autoimmunity 4: 237-248

114. Hutchings P, Rosen H, O'Reilly L, Simpson E, Gordon S, Cooke A (1990) Transfer of diabetes in mice prevented by blockade of adhesion-promoting receptor in macrophages. Nature 348: 639-642

115. Shizuru J, Taylor-Edwards C, Banks BA, Gregory AK, Gathman CG (1988) Immunotherapy of the nonobese diabetic mouse: treatment with an antibody to T-helper lymphocytes. Science 240: 659-661

116. Koike T, Itoh Y, Ishii T et al. (1987) Preventive effect of monoclonal anti-L3T4 antibody on development of diabetes in NOD mice. Diabetes 36: 539-541

117. Like AA, Biron CA, Weringer EJ, Byman K, Sroczinski E, Guberski DL (1986) Prevention of diabetes in biobreeding/Worcester rats with monoclonal antibodies that recognize T lymphocytes or natural killer cells. J Exp Med 164: 1145-1159

118. Boitard C, Timsit J, Sempé P, Bach JF (1991) Experimental immunoprevention of type 1 diabetes mellitus. Diabetes Metab Rev 7: 15-33
119. Sempé P, Bedossa P, Richard MF, Villa MC, Bach JF, Boitard C (1991) Anti- $\alpha \beta$ T cell receptor monoclonal antibody provides an efficient therapy for autoimmune diabetes in NOD mice. Eur J Immunol 21: 1163-1169

120. Charlton B, Bacelj A, Slattery RM, Mandel TE (1989) Cyclophosphamide-induced diabetes in NOD/WEHI mice. Diabetes 38: 441-447

121. Dardenne M, Lepault F, Bendelac A, Bach JF (1989) Acceleration of the onset of diabetes in NOD mice by the thymectomy at weaning. Eur J Immunol 19: 889-895

122. Boitard C, Yasunami R, Dardenne M, Bach JF (1989) T-cell mediated inhibition of the transfer of autoimmune diabetes in NOD mice. J Exp Med 169: 1669-1680

123. Zipris D, Crow AR, Delovitch TL (1991) Altered thymic and peripheral T-lymphocyte repertoire preceding onset of diabetes in NOD mice. Diabetes 40:429-435

124. Zipris D, Lazarus AH, Crow AR, Hadzija M, Delovitch TL (1991) Defective thymic T cell activation by concanavalin $A$ and anti-CD3 in autoimmune nonobese diabetic mice. J Immunol 146: 3763-3771

125. Savino W, Boitard C, Bach JF, Dardenne M (1991) Studies on the thymus in the nonobese diabetic mouse. I. Changes in the microenvironmental compartments. Lab Invest 64: 405-417

126. Nabarra B, Andrianarison I (1991) Thymus reticulum of autoimmune mice. 3. Ultrastructural study of NOD (non-obese diabetic) mouse thymus. Int J Exp Path 72: 275-287

127. Todd JA, Bell JI, McDevitt HO (1987) HLA-DQ $\beta$ gene contributes to susceptibility and resistance to insulin-dependent diabetes mellitus. Nature 329: 599-604

128. Bacelj A, Charlton B, Mandel TE (1989) Prevention of cyclophosphamide-induced diabetes by anti-V $\beta 8$ T-lymphocyte-receptor monoclonal antibody therapy in NOD/Wehi mice. Diabetes 38: 1492-1495

129. McDuffie $M$ (1991) Diabetes in NOD mice does not require T lymphocytes expression V $\beta 8$ or V $\beta 5$. Diabetes 40: 1555-1559

130. Shizuru J, Taylor-Edwards C, Livingstone A, Fathman CG (1991) Genetic dissection of T cell receptor V $\beta$ gene requirements for spontaneous murine diabetes. J Exp Med 174: 633638

131. Shizuru J, Taylor-Edwards C, Livingstone A, Fathman CG (1991) Genetic dissection of T cell receptor V $\beta$ gene requirements for spontaneous murine diabetes. J Exp Med 174: 633638

132. Livingstone A, Edwards CT, Shizuru JA, Fathman CG (1991) Genetic analysis of diabetes in the nonobese diabetic mouse. I. $\mathrm{MHC}$ and $\mathrm{T}$ cell receptor $\beta$ gene expression. J Immunol 146: $529-534$

133. Haskins K, Portas M, Bradley B, Wegmann D, Lafferty K (1988) T-lymphocyte clone specific for pancreatic islet antigen. Diabetes 37: 1444-1448

134. Reich EP, Sherwin RS, Kanagawa O, Janeway CA Jr (1989) An explanation for the protective effect of the MHC class II I-E molecule in murine diabetes. Nature 341: 326-328

135. Haskins K, Portas M, Bergman B, Lafferty K, Bradley B (1989) Pancreatic islet-specific T-cell clones from nonobese diabetic mice. Proc Natl Acad Sci USA 86: 8000-8004

136. Pankewycz O, Strom TB, Rubin-Kelley VE (1991) Islet-infiltrating $\mathrm{T}$ cell clones from non-obese diabetic mice that promote or prevent accelerated onset diabetes. Eur J Immunol 21: 873879

137. Elias D, Reshef T, Birk OS, van der Zee R, Walker MC, Cohen IR (1991) Vaccination against autoimmune mouse diabetes with a T-cell epitope of the human $65-\mathrm{kDa}$ heat shock protein. Proc Natl Acad Sci USA 88: 3088-3091

138. Elias D, Markovits D, Reshef T, van der Zee R, Cohen IR (1990) Induction and therapy of autoimmune diabetes in the non-obese diabetic (NOD/Lt) mouse by a $65-\mathrm{kDa}$ heat shock protein. Proc Natl Acad Sci USA 87: 1576-1580

139. Bradley BJ, Wang Y, Lafferty KJ, Haskins K (1990) In vivo activity of an islet-reactive T-cell clone. J Autoimmunity 3: 449 456 
140. Haskins K, McDuffie M (1990) Acceleration of diabetes in young NOD mice with a CD4 + islet-specific T cell clone. Science 249: 1433-1436

141. Escurat M, Djabali K, Huc Cet al. (1991) Origin of the beta cells of the islets of Langerhans is further questioned by the expression of neuronal intermediate filament proteins, peripherin and NF-L, in the rat insulinoma RIN5F cell line. Dev Neurosci 13: 424-432

142. Boitard C, Villa MC, Bécourt Cet al. (1992) Peripherin: an islet antigen that is cross-reactive with nonobese diabetic mouse class II gene products. Proc Natl Acad Sci USA 89: 172-176

143. Boitard C, Pham-Gia H, Bécourt C, Bach JF (1989) Réaction croisée entre les antigènes de classe II du complexe majeur d'histocompatibilité de la souris NOD et un antigène insuline de poids moléculaire de $58 \mathrm{kDa}$. C R Acad Sci Paris 309: 229 234

144. Atkinson MA, MacLaren NK (1988) Autoantibodies in nonobese diabetic mice immunoprecipitate $64,000-\mathrm{M}_{\mathrm{r}}$ islet antigen. Diabetes 37: 1587--1590

145. Schreiber SL (1991) Chemistry and biology of the immunophilins and their immunosuppressive ligands. Science 251: 283-287

146. Liu J, Farmer JD, Lane WS, Friedman J, Weissman I, Schreiber SL (1991) Calcineurin is a common target of cyclophilin-cyclosporine A and FKBP-FK506 complexes. Cell 66:807-815

147. Zhang ZJ, Davidson L, Eisenbarth G, Weiner HL (1991) Suppression of diabetes in nonobese diabetic mice by oral administration of porcine insulin. Proc Natl Acad Sci USA 88: 1025210256

148. Kelley VE, Gaulton GN, Hattori M, Ikegami H, Eisenbarth G, Strom TB (1988) Anti-interleukin 2 receptor antibody suppresses murine diabetic insulitis and lupus nephritis. J Immunol 140: 59-61

149. Pacheco-Silva A, Bastos MG, Muggia RA et al. (1992) Interleukin 2 receptor targeted fusion toxin (DAB486-IL-2) treatment blocks diabetogenic autoimmunity in non-obese diabetic mice. Eur J Immunol 22:697-702

150. von Boehmer H, Kisielow P (1990) Self-nonself discrimination by $\mathrm{T}$ cells. Science $248: 1369-1372$

151. Blackman M, Kappler J, Marrack P(1990) The role of the T cell receptor in positive and negative selection of developing $T$ cells. Science 248: 1335-1341

152. Nossal GJV (1989) Immunologic tolerance: collaboration between antigen and lymphokines. Sciences $245: 147-153$

153. Marrack P, Kappler J (1987) The T cell receptor. Science 238: 1073-1079
154. Ohashi PS, Oehen S, Buerki K et al. (1991) Ablation of "tolerance" and induction of diabetes by virus infection in viral antigen transgenic mice. Cell 65:305-317

155. Schartz RH (1990) A cell culture model for T lymphocyte clonal anergy. Science 248: 1349-1356

156. Hayward AR, Shriber M(1989) Neonatal injection of CD3 antibody into nonobese diabetic mice reduces the incidence of insulitis and diabetes. J Immunol 143: 1555-1559

157. Hayward AR, Shriber M (1992) Reduced incidence of insulitis in NOD mice following anti-CD3 injection: requirement for neonatal injection. J Autoimmunity 5: 59-67

158. Shintani S, Satoh J, Seino H, Goto Y, Toyota T (1990) Mechanism of action of a streptococcal preparation (OK-432) in prevention of autoimmune diabetes in NOD mice. J Immunol 144: $136-141$

159. Sadelain MWJ, Sin HY, Lauzon J, Singh B (1990) Prevention of type 1 diabetes in NOD mice by adjuvant immunotherapy. Diabetes 39: 583-589

160. Boitard C, Sempé P, Villa MC et al. (1991) Monoclonal antibodies: probes for studying experimental autoimmunity in animals. Res Immunol 142: 495-503

161. Guberski DL, Thomas VA, Shek WR et al. (1991) Induction of type 1 diabetes by Kilham's rat virus in diabetes-resistant $\mathrm{BB} /$ Wor rats. Science 254: 1010-1013

162. Oldstone $C$ (1987) Prevention of type 1 diabetes in nonobese diabetic mice by virus infection. Science 239: 500-502

163. Leiter EH, Christianson GJ, Serreze DV, Ting AT, Worthen SM (1989) MHC antigen induction by interferon $\gamma$ on cultured mouse pancreatic $\beta$ cells and macrophages. Genetic analysis of strain differences and discovery of an "occult" class I-like antigen in NOD/Lt mice. J Exp Med 170: 1243-1262

164. Sarvetnick N, Shizuru J, Liggitt D et al. (1990) Loss of pancreatic islet tolerance induced by $\beta$-cell expression of interferon- $\gamma$. Nature 346: 844-847

165. Anderson GD, Banerjee S, Luthra HS, David CS (1991) Role of Mls- 1 locus and clonal deletion of T cells in susceptibility to collagen-induced arthritis in mice. J Immunol 147: 1189-1193

Prof. C. Boitard

Immunologie Clinique

Hôpital Necker

161 rue de Sèvres

F-75743 Paris Cedex 15

France 